\title{
Groping towards Morality: Feminism, AIDS, and the Spectre of Article 41 in Thomas Kilroy's Ghosts
}

\author{
José Lanters \\ University of Wisconsin-Milwaukee, USA
}

Copyright (c) 2018 by José Lanters. This text may be archived and redistributed both in electronic form and in hard copy, provided that the author and journal are properly cited and no fee is charged for access.

\begin{abstract}
When Thomas Kilroy adapted Henrik Ibsen's Ghosts in 1989, he relocated the action of the play to an Irish provincial town in the mid-1980s. He retained Ibsen's focus on loveless marriage but changed the son's affliction, syphilis - Ibsen's metaphor for "the devitalizing effect of inherited convention", the real "ghosts" of the past - to HIV-AIDS. These various changes allowed Kilroy to include echoes of the 1986 Irish divorce referendum and the developing international AIDS crisis in his play. One ghost stalking Kilroy's adaptation is Article 41 of the Irish Constitution which relates to "The Family" and particularly affects the position of women. Kilroy's Ghosts not only confronts the spectre of that document but anticipates significant changes that would be made to it in subsequent decades: the legalization of divorce after a second referendum in 1995, and the legalization of same-sex marriage as a result of the 2015 marriage equality referendum.
\end{abstract}

Key Words. Adaptation, Marriage, Family, HIV-AIDS, Morality.

Resumen. Cuando en 1989 Thomas Kilroy adaptó Ghosts, de Henrik Ibsen, situó la acción de la obra en una ciudad de provincias de Irlanda a mediados de los años 80 del pasado siglo. Mantuvo el foco de la trama ideada por Ibsen en el matrimonio desavenido, pero sustituyó la enfermedad del hijo, sífilis (que Ibsen utilizaba como metáfora para destacar "el efecto debilitador de las convenciones heredadas", los "fantasmas" reales del pasado) por el VIHSIDA. Estas variaciones permitieron a Kilroy incluir en su obra ecos del referendum sobre el divorcio de 1986, así como la crisis mundial del SIDA que se extendía en esa época. Uno de los fantasmas que acechan al espectador en la adaptación de Kilroy es el artículo 41 de la Constitución de Irlanda, un artículo que tiene que ver con "La familia" y que tiene una especial relevancia en torno al papel asignado a las mujeres. Ghosts, en versión de Kilroy, no sólo se enfrenta al espectro que supone dicho documento, sino que anticipa una serie de modificaciones que se le harían al mismo en las siguientes décadas, concretamente las leyes sobre la legalización del divorcio tras el segundo referéndum en 1995 y la legalización del matrimonio entre personas del mismo sexo que tuvo lugar tras la consulta de 2015. 
Palabras clave. Adaptación, matrimonio, familia, VIH-SIDA, moralidad.

\section{Introduction}

In 1985, legendary actress Siobhán McKenna and theatrical producer Phyllis Ryan were planning a production of Arsenic and Old Lace at Dublin's Gaiety Theatre. As Ryan later recalled it, the two drifted into a conversation about marriage and found themselves talking about Henrik Ibsen's Ghosts, which they both considered "one of the most important plays ever written about the attitudes to and complexities of women in the marital stakes". The relevance of the play for "an Irish situation" struck them in particular. Both were familiar with the success of Thomas Kilroy's adaptation of Anton Chekhov's The Seagull, first performed in 1981 at London's Royal Court Theatre, which relocates the action from Russia to an Anglo-Irish country estate; they agreed to ask the playwright whether he might write a version of Ghosts that would "bring it to an Irish setting, up-date it and still retain Ibsen's original concept" (Ryan, Programme Note). Kilroy declined, however, since he was in the process of finishing his play Double Cross for Field Day while also trying to complete a novel (Angela, which remains unpublished). When McKenna died in November 1986, Ryan put the project on hold, but renewed the invitation in late December 1987: "please, Tom Kilroy", she wrote, "make my year, and let me be happy in 1988" (Letter, 30 December 1987). This time Kilroy "agreed to bring Ghosts to Ireland, with Ibsen's truths preserved" (Ryan, Programme Note). The play was produced by the Abbey Theatre, in association with Ryan's Gemini Productions, at the Peacock Theatre, Dublin, in October 1989.

Kilroy has made the point that "the history of European theatre ... is a history of adaptation" - a history of "variation, imitation and recycling of other material" ("Adaptation" 47). His original plays often reflect the influence of works by other writers or of specific productions by which he felt inspired; conversely, his adaptations are invariably infused with ideas and themes explored elsewhere in his own oeuvre. Indeed, while Kilroy regards the process of adapting a classic play for the contemporary stage as, in many respects, "journeywork" that has much to do with "the practical business of making theatre" ("Playwrights" 176), he will only take on such projects if he feels personally affected by the work in a way that will allow him both to respect the objectives of the original and to find "a degree of freedom" to express his own angle of vision (Roche 155). Kilroy felt he could only write his adaptation of Ibsen's Ghosts "by thinking in terms of contemporary Irish mores" (O'Byrne 14), and therefore relocated the play not only from Scandinavia to Ireland but also from the past to the present. Placing the action in the mid-1980s allowed him to include echoes of two hot-button issues of that period: the Irish divorce referendum of 1986, and the developing AIDS crisis that disproportionately affected the gay community at home and abroad. Kilroy's interest in questions of gender and sexuality goes back to some of his earliest plays, The Death and Resurrection of Mr Roche (1968) and Tea and Sex and Shakespeare (1976). In the former, the homophobia expressed by a group of men towards Mr Roche, a gay man of their acquaintance, is used as a vehicle to examine bigotry and self-deception as manifestations of a sick society; the latter play focuses on a writer who suffers a creative and psychological breakdown coinciding with a crisis in his marriage. In his version of Ghosts, Kilroy attempts to address similar themes within the confines of Ibsen's plot structure, giving himself license to use his imagination without losing sight of the drama's original premise. 


\section{Loveless Marriage in Ibsen and Kilroy}

Ibsen's Ghosts is a work dealing with the long-term consequences of an unhappy marriage symbolized by the congenital syphilis transmitted by the father to his blameless son. When the text of the play was originally published in Copenhagen in 1881, it was received with outrage and hostility. Scandinavian theatre managers refused to produce what they considered an immoral work; the play's world premiere therefore took place in Chicago in 1882, in front of an audience of Scandinavian immigrants. However, by the time Ghosts was staged in Sweden the following year the mood had shifted, and the play was favourably received; in 1890, when it finally received its first fully Norwegian production, audiences "marvelled that the play could ever have excited such paroxysms of horror" (Meyer 113). The initial scandalized responses to Ghosts were largely due to the fact that Ibsen's contemporaries saw the work "primarily as a play about inherited physical illness" rather than "the devitalizing effect of inherited convention" - the real "ghosts" of the past (Meyer 120). One of the inherited conventions criticized most forcefully in the play is the institution of marriage, particularly the marriage of convenience entered into for reasons other than love.

Central to Kilroy's writing is a concern with "the quest for the truth" that involves "cutting through illusion" (Battersby 13), a quality of outspokenness he shares with his Norwegian counterpart. At the end of February 1988, Kilroy wrote to Ryan: "I think my play is going to be about AIDS in the sense in which Ibsen's is about syphilis. But like Ibsen my version will be essentially about loveless marriage". Kilroy quoted a line from Ibsen's notes on Ghosts - "Marriage for external reasons even when these are religious or moral brings a nemesis upon the offspring", later used as the epigraph to the published text of the adaptation - and explained his personal connection with this theme, noting that his own first marriage "was an unhappy one" (Kilroy, Letter). When the play opened in 1989 as part of the Dublin Theatre Festival he told a panel hosted by theatre critic John Elsom that his version of Ghosts was "the most autobiographical thing" he had ever written for the stage ("Energetic Elsom" 25).

In both Ibsen's original and Kilroy's version, it is the women as well as the children who suffer the negative consequences of an unhappy marriage. In his programme note for the 1989 production of his adaptation, Kilroy recalls Siobhán McKenna speaking to him

about attitudes in Irish society towards women and why Ghosts would be all too easily adapted to an Irish setting. She said wasn't it some kind of terrible comment that the crawthumping puritanism, the withered fear of women which Ibsen wrote against so passionately in his native Norway could still exist in our own country over one hundred years after the first appearance of Ghosts. (Kilroy, Programme Note)

Ibsen, in his notes on the play, wrote that restrictions and hardships imposed by society on women have negative repercussions for the future: "These women of the present day, ill-used as daughters, as sisters, as wives, not educated according to their gifts, prevented from following their inclination, deprived of their inheritance, embittered in temper - it is these who furnish the mothers of the new generation. What is the result?" (Ibsen, Workshop 185). Ryan remembered talking to McKenna about Ibsen and women's liberation, and agreeing with her that, "while a few women had emancipated themselves, the main wave of ordinary Irish women were in much the same situation they had always been in". She put part of the blame for this on "backward-looking teaching from both Church and schools; a ghost of the past stalking the present" (Wallace 14). 


\section{Article 41 and the Family}

In Ireland, one such ghost of the past stalks the present in the form of Article 41 of the Constitution which relates to "The Family". To this day, much of the language remains unchanged from that of the document composed in 1937 during Eamon de Valera's administration. The Article stipulates that the Family is recognized and guaranteed protection by the State as "a moral institution" that forms "the necessary basis of social order" and is "indispensable to the welfare of the Nation and the State". Women are considered central to the success of the family unit: "In particular, the State recognises that by her life within the home, woman gives to the State a support without which the common good cannot be achieved". Given this prioritization of the domestic role of married women, premised on the assumption that they have children, the State endeavours "to ensure that mothers shall not be obliged by economic necessity to engage in labour to the neglect of their duties in the home". Separate legislation passed in the 1930s (removed in the 1970s) barred married women from working as primary school teachers and from employment in the civil service, local authorities, and health boards. In the Constitution, the State also undertook "to guard with special care the institution of Marriage, on which the Family is founded, and to protect it against attack": divorce was therefore prohibited.

When, in 1986, the Fine Gael government led by Dr Garret FitzGerald moved to hold a referendum on the removal from the Constitution of the divorce ban, the Catholic hierarchy issued a statement spelling out the reasons why the electorate should vote against the proposed change. Raising the question of the relationship between the law and morality, the bishops made the case that, while morality cannot be legally enforced, certain kinds of law "can make virtue more difficult and non-virtue more likely". Divorce, they argued, does not just affect broken marriages: "All existing marriages are in principle implicated". Children, the statement went on, are likely to suffer more from the shock of their parents' divorce and remarriage than from tension and unhappiness at home. Citing the growing number of children with divorced parents in Britain, the bishops warned against the "escalator effect of divorce" were it to become available ("Irish Bishops" 15). In the run-up to the referendum, however, the anti-divorce campaign tended to focus less on the moral effects of divorce and more on its implications for property and pension rights, and it was such material concerns that led to the defeat of the proposal in the referendum by a two to one margin. The divorce ban was eventually removed from the Constitution after a second referendum in 1995, in which the "yes" vote prevailed.

\section{Contemporizing Ibsen}

As he was considering how to translate Ibsen's themes to contemporary Ireland, Kilroy conveyed his preliminary ideas to Ryan in a letter:

I see a widow of substantial means living in the Dublin suburbs. The dead husband a prominent solicitor - business man, connected to politics (large public reputation) a world-traveller, a secret degenerate. Pastor Manders becomes a priest, Jesuit, perhaps, one of whose public roles is working with the underprivileged and street culture. The boy is ill from the rise of the curtain, otherwise I have a problem with the one day, one night time span. Drugs? Bisexuality? Regina may be the only character to retain her Ibsenite name. (Kilroy, Letter) 
Commenting on a draft of the play in spring 1988, Christopher Fitz-Simon noted some immediate problems with this updated scenario:

[the priest] would be totally believable if the play was set in the 30's or 40's [ sic]. But then AIDS would not be about, and anything else is now curable. Ibsen set his play in a country house and not in the suburbs of a city. If Tom's play was set in a house in the provinces ... the priest would become more believable, although he cannot be quite so naive as he is at present. (Fitz-Simon, Comments)

Kilroy eventually set the play in "a house on the outskirts of a small Irish provincial town" in the mid-1980s (Kilroy, Ghosts 8). In a rural context it made no sense for the Catholic priest, called Fr Manning in Kilroy's version, to be a member of an intellectual order working with down-and-outs; in the finished version of the text he has become a deliberately old-fashioned cleric, out of touch with the younger generation. "I never know where I am these days with young people", he tells Regina before reminding her of her "duty" to her father, which he knows is "not a fashionable word nowadays" (12). The priest's backward-looking attitude is especially evident when he tells Oliver Aylward (Ibsen's Oswald Alving) that freedom is "old hat" and that yesterday's morals and values are fast returning: "Young people of my acquaintance now are flocking back to religion ... Illicit unions are being regularized. Order is being restored" (23). Fr Manning, then, is the kind of priest "whose life is frozen in an outdated attitude" and whose mentality represents "the backlog of pre-Vatican Two Church teaching" that, Ryan maintained, was "still present in Ireland" in the 1980s (Wallace 14).

Kilroy streamlined and, to some extent, reorganized Ibsen's material. He cut the rather cumbersome opening scene between Regina and her father Engstrand (called Jacko English in his version) and confined the latter's physical presence in the play to a brief appearance towards the end. The twentieth-century characters in Kilroy's adaptation, not restricted by the social niceties of Ibsen's age, are more outspoken throughout than their Ibsenite counterparts. Rather than being superficially polite and somewhat subservient in manner, the contemporary Regina, though still a housekeeper in the Aylward household, is openly sullen and resentful, only occasionally paying lip-service to her socially inferior position by modifying her strong opinions with phrases like, "I know I shouldn't be saying that" (Kilroy, Ghosts 11). At times the difference in tone between the two versions of the play is striking. Ibsen's Regina, for example, pleads with Pastor Manders not to make her go and live with her father but to find her an alternative:

REGINA: Oh, I'd so love to go and live in the city. Out here it's so dreadfully lonely - and you know, don't you, sir, what it means to be all alone in the world? And I'm quick and willing - I think I can say that. Oh, Pastor Manders, don't you know of a place I could go to? (Ibsen, Ghosts 136)

Kilroy's Regina is almost sarcastic when she refuses to contemplate living with her father and running a B\&B for him, telling Fr Manning that she would as soon be a "skivvy" for a prospective husband: "Maybe I'll put an ad in the paper. Respectable maid. Clean. Good worker. Anxious to meet fat farmer. Send photo" (Kilroy, Ghosts 13). In Fintan O'Toole's opinion, playing down the melodrama greatly improved the play: Kilroy, he suggested, "makes it hard, angry and at times chilling" (25). While David Nowlan also liked the "multiple layers of added ironies to the original script", his one criticism was that the new version "remains couched in old-fashioned dramatic structures" and contains some stilted dialogue (12). Indeed, while Kilroy's own plays often include unconventional and 
experimental elements, Ghosts does not take great liberties with form and technique. Perhaps aware of some of these issues, Kilroy commented with hindsight on the limitations the original material had imposed on him by comparing Ibsen's dramatic style with that of Chekhov: Chekhov's is "a much more random world ... where unusual things can happen", he argued, whereas the same fluidity is not part of the other playwright's territory: "There is a sternness and a rigour to Ibsen which precludes this". That rigour may work against the adaptor, for whom there is in any case always "a line that you cannot cross. Maybe you cannot see the line. You have to be careful at all times in that regard" ("Playwrights" 176).

\section{Abused Women and Children}

Christopher Murray notes that one of the extraordinary achievements of Kilroy's Ghosts is that it manages, in the late 1980s, to move "beyond ... topicality into prophecy" by foreseeing the wave of revelations about clerical abuse that would wash over Ireland from the 1990s onward ("Panel Discussion 1" 68). In Kilroy's adaptation, the orphanage of the original play has become a home for battered women, funded by Mrs Aylward with her late husband's money. Fr Manning's concern not to have his name associated with the project comes with a whiff of scandal: "It's these journalists. You know what they tried to do to me in the past over money. They would crucify me if they had half a chance" (Kilroy, Ghosts 17). Indeed, he argues, "the media in this country are out to destroy the Church" (18). After the women's shelter burns down, the wily Jacko English is able to extort hush money from Fr Manning by threatening to involve the press: "They do love digging up things about places like hospitals and schools and homes and that class a' thing" (50-51). When the priest berates Oliver for surrendering himself to "gross immorality", the young man turns the tables on Fr Manning, revealing his intimate knowledge of the reprehensible sexual mores of the corrupt businessmen and politicians "who wine and dine the clergy": "By God, when it all comes out, that'll be the day! All the dirty linen of the Faith of our Fathers!" (24). Kilroy later washed much of that dirty linen in public in Christ, Deliver Us! (2010), his version of Frank Wedekind's Frühlings Erwachen, which is set in Ireland in the 1950s and addresses the role of the clergy in the abuse scandals that had come to light in the preceding decade.

For Murray, the feminist statements Kilroy puts into Mrs Aylward's mouth also "reach forward to what was at the time concealed beneath the surface of Ireland's social revolution" ('Panel Discussion 1" 68). The books she has been reading, which in Ibsen's text are generically reflective of "intellectual movements in the great world outside" (Ibsen, Ghosts 139), in Kilroy's version are specifically described by a disapproving Fr Manning as "[a]ttacks on the home, the family, on womanhood" (Kilroy, Ghosts 16) - a choice of words in which the ghost of Article 41 is very much present. The books have apparently opened Mrs Aylward's eyes to the detrimental teachings of the past that have led to Ireland in the present being "full of haunted, suffering people. Specially women. Oh, yes. Always women" (34). What she holds against Fr Manning personally is that years earlier, when she left her husband and came to him for help and comfort, he sent her back into the loveless marriage by arguing that she had accepted her wedding vows and it was therefore her "duty to live with them" (27). When her husband subsequently fathered a daughter with Joanna, the housekeeper, she "covered his tracks for him" and stood by him: "I was the perfect wife! Yes. Smiling and nodding in public. Is it ever any other way for women?" (31).

In trying to shield her son Oliver from the truth about his father by sending him away, she instead made him feel rejected and unloved: "I think I may have destroyed your life, Oliver", she realizes belatedly. 
MRS AYLWARD: (Lost in thought) They taught me how to be a good wife. They taught me how a woman should keep her place. A woman has the greater role to play in life, they said. Did you ever hear such rubbish? A woman has to lead men in the path of virtue, they said. Oh, how well they know how to control women! Women are so easily tricked by appeals to their virtue. Make them feel good and they'll do anything ... (56)

As Murray points out, while such language struck "a topical note" in 1989, "it was written before Mary Robinson was elected president of Ireland and before women's voices were raised against the church and all the abuse of which it was to be found guilty" ("Panel Discussion 1" 69). In 1997, Kilroy would make the protagonist of his play The Secret Fall of Constance Wilde express similar sentiments: "What you have to understand is that we women are trained from birth to conceal", Constance tells Alfred Douglas; "Otherwise, you see, men would be unable to behave as they do. This is what is known as society" (30).

\section{The AIDS Crisis}

Fintan O'Toole and other reviewers felt that Kilroy's use of HIV-AIDS had created "a convincing and complex psychological substitute for Ibsen's retributive God of syphilis" (25). While Oswald's affliction is never mentioned by name in Ibsen's play and he appears outwardly unaffected by the disease that is beginning to take its toll on his brain, Kilroy's Oliver is a visibly sick man. At the very beginning of the play Regina mentions to Fr Manning how "terrible" he looks, and how he sweats at night: "The sheets are wringing wet every morning when I touch them" (Kilroy, Ghosts 11). His mother, too, observes how "gaunt" he is, to the point where "people no longer recognize him" (14), but she and the priest play down these symptoms out of denial or ignorance. The son's revelation to his mother of the true nature of his condition contains a direct nod to Ibsen:

MRS AYLWARD: (Pause) Is it syphilis?

OLIVER: No, it's not. It's infinitely worse.

MRS AYLWARD: Worse!

OLIVER: ... I've been diagnosed HIV positive. I've already developed some of the classic symptoms of immune deficiency.

MRS AYLWARD: Jaysus, Mary and Joseph! That thing they're talking about in the papers? (41)

If this dialogue sounds overly explanatory, it is in part because Kilroy was dealing with relatively new information, especially in an Irish context. HIV had only been adopted as the name of the retrovirus in 1986; the antiretroviral drug AZT became available in 1987; and the first World AIDS Day took place in December 1988. Michael Scott, who directed Kilroy's Ghosts in 1989, had "fought" in 1987 to bring Larry Kramer's play The Normal Heart to Ireland, but found that the media were highly reluctant to deal with HIV or AIDS: "it was taboo and in fact in Ireland, nobody officially knew anything about HIV or Aids [sic] at all" ("Panel Discussion 2" 84).

In Kilroy's adaptation, what Oliver has inherited from his father is not the virus but the man's promiscuous nature. In Ibsen's play, Oswald contracted syphilis from his father's pipe, which Alving indulgently allowed his young son to puff. In Kilroy's version, the permissive father used the pipe for smoking pot, as Oliver recalls: "Sitting on my Daddy's knee. The two of us high as kites. 'Here, my boy. Have a drag'. And he puffed. And I puffed. And we went down the Sewanee river together" (Kilroy, Ghosts 21). Mrs Aylward suggests that the "sins of 
the father" have been visited upon the son via inherited character flaws: "Hasn't he infected you with his filthy habits? ... You're just like him!", she tells Oliver (41-42). David Nowlan suggests that this shift makes the transmission of blame from father to son "human" rather than biological (12). However, the implication that "filthy habits" led to Oliver contracting HIV also runs the risk of playing into the assumption, common at the time of the play's premiere, that AIDS is a disease of promiscuity. In an informational notice headed "AIDS: The Facts", published in Irish newspapers in 1987 by the Health Education Bureau, the public were warned that " $[\mathrm{t}]$ here is no known cure for AIDS and death is certain after a period of physical and sometimes mental degeneration". Apart from intravenous drug users, the groups listed in the publication as being at risk of contracting the virus included "Gay men and Bisexual men" if "they are promiscuous", and "Promiscuous Heterosexual Males and Females" or the partners "of a promiscuous person" ("AIDS: The Facts" 3). A Statement on AIDS issued in 1987 by the Catholic hierarchy suggested that the disease was associated with "moral disorder" and had its roots in "drug abuse and sex abuse" ("Statement on AIDS" 6). Cormac O'Brien notes that this kind of AIDS-as-punishment rhetoric is also prevalent in Irish theatre dealing with the AIDS crisis: plays often suggest to the spectator "that people contract HIV because of misdeeds in earlier life, or the type of person they are, or where they come from, rather than as a result of a contingent encounter with another HIV-positive individual" (7).

Oliver's sexuality remains unspecified in Kilroy's version of the play: he might be gay or bisexual, as the playwright had considered making him in the proposal he initially sent to Ryan, but is not overtly one or the other. A reviewer of the American premiere picked up "signs that Oliver is gay" and noted a consequence of such an interpretation for another strand of Ibsen's plot: "the threat of incest is dissipated" (Williams-Rude). Playing down the nature of Oliver's sexual preferences allows the incest idea in the original plot - a potential union between Oliver and Regina - to remain viable, and avoids the danger of stereotyping AIDS as a "gay" disease, but also makes it more difficult to get any real sense of the character's sexual life at all. This is an issue insofar as a destructive and "ghostly" link between father and son is necessary for the play to remain faithful to Ibsen's core intentions, while the substitution of AIDS for syphilis necessitates that the link between father and son be psychological, in the form of promiscuity as a shared character flaw; but in Kilroy's version there is, in fact, very little to back up that salacious aspect of Oliver's nature.

What Oliver does share with his father is the casual ease with which he exploits women. His cultivation of Regina is entirely self-serving and based on the calculation that she "has the guts to do what has to be done" (Kilroy, Ghosts 54) when the time comes for him to end his life. The revelation that Regina and Oliver have the same father, however, releases in the young woman a sense of bitterness that prompts her to turn first on Mrs Aylward "Women this and women that. But what about me?" - and then her son: "I thought there might be something between us ... What a laugh! ... I'm not a nurse or something. No way" (57). Determined to have nothing more to do with Oliver and his mother, she cynically decides instead to "latch onto" Fr Manning to obtain her share of the money left by Aylward, signed over to the Church by his widow now that the shelter for abused women that bore the adulterer's name has burned to the ground. Her other option is to take up Jacko English's offer to set her up in his new B\&B, even as she realizes that he is "a right pimp and no mistake" (58). Regina's material survival may be guaranteed, but (to borrow Ibsen's language from his notes on women), this ill-used daughter and sister, not educated according to her gifts - "the least you could have done was send me for training", she tells Mrs Aylward (58) and prevented from following her inclination, is left "embittered in temper" (Ibsen, Workshop $185)$ to carry the evil ghost of the past into the future. 


\section{Same-Sex Unions}

While Oliver is prepared to take unscrupulous advantage of Regina's presence in his mother's home to serve his own ends, he adopts a moral position when it comes to fiercely condemning the six businessmen who, he relates, one day arrived on his Paris doorstep:

Over for a high level conference, no less. Got my address from Mother here. Looking for a bit of action, they said. And given my arty life could I set them up. They listed their needs. Every kink in the book. I just listened. (Kilroy, Ghosts 25)

At the same time, he takes particular umbrage at Fr Manning's condemnation of "illicit unions" while expressing great sympathy for the unorthodox but loving and stable families he knew in the French capital:

OLIVER: Do you mean man and woman? Or man and man? Or woman and woman? Or some other combination? ...

FR MANNING: I'm certainly not talking about abnormality -

OLIVER: - thought we were talking about love -

FR MANNING: - love! Indeed!

OLIVER: You don't think homosexuals can express love? ...

FR MANNING: And children?

OLIVER: What about them?

FR MANNING: - exposed to this kind of thing?

OLIVER: (Slowing down again) I've seen children exposed, as you put it, to this kind of thing. Growing up perfectly normal, as you put it. But without fear, without disgust, without guilt. (23-24)

In 1995, at the time of the second divorce referendum, a committee was established by the Irish government to review the Constitution and recommend changes; in the section on "The Family" in its report, the Constitution Review Group advised that, while it favoured retaining the pledge by the State to guard with special care the institution of marriage, this "should not prevent the Oireachtas from providing protection for the benefit of family units based on a relationship other than marriage" (310). Such alternative units - Fr Manning's "illicit unions" - might include cohabiting heterosexual couples with or without children; unmarried lone parents and their children; and homosexual and lesbian couples (298); it does not appear to have occurred to the writers of the report, however, that gay couples might also have children. Oliver's passionate humanitarian plea in Kilroy's Ghosts is therefore once more extraordinarily forward-looking, and anticipates by decades the "yes" arguments leading up to the 2015 marriage equality referendum that legalized same-sex unions in Ireland and led to the addition of a clause to Article 41 that marriage "may be contracted ... by two persons without distinction as to their sex". Oliver's argument in this instance does not make him sound like a man who has inherited his father's "filthy habits". For Kilroy's switch from a biological to a psychological transmission of the father's sins to make complete sense, Oswald's character would have had to be more drastically altered: but that would doubtless have destabilized other aspects of Ibsen's drama, not least his critique of the moral flaws inherent in traditional notions of marriage. 


\section{Groping towards Morality}

Fintan O'Toole considered Kilroy's adaptation a "splendid meeting of minds between contemporary Ireland and a European classic" (25), while for Mary O'Donnell of the Sunday Tribune the play managed to be "at once recognisable as essential Ibsen and essential Kilroy" (B3). Those essentially Kilrovian elements manifest themselves in a deep concern with the gap between private and public conduct, and with the realization that life and love are not morally straightforward but messy and contested - that love, as Kilroy puts it in Henry, his free adaptation of Pirandello's Enrico IV (2005), is something "we must constantly invent" (127). In Ghosts the section of dialogue between Mrs Aylward and Fr Manning added by Kilroy to Ibsen's text in Act I, just before the two characters discuss the controversial books on the living-room table, illustrates the way in which he places his own emphases:

MRS AYLWARD: ... Are you sure going around doing good, as you see it, doesn't sometimes cause great suffering?

FR MANNING: (Pause) That's a strange notion and no mistake. (Pause) I'm not sure about everything. I don't pretend to know - everything. But one thing I am sure of is the teaching of our Lord and Saviour Jesus Christ.

MRS AYLWARD: I think we have to grope towards our morality every hour of every day of our lives ... (15)

Kilroy and Ibsen, then, deal differently with the notion of personal guilt and responsibility. When Ibsen's Oswald first tells his mother about his diagnosis of syphilis, he still believes what she wrote him in her letters: that his father was an honourable man. He therefore concludes that his disease, which his doctor at first (and, as it turns out, correctly) declared to be congenital, is his own fault and the result of his own frivolous actions. Kilroy's Oliver, by contrast, is in possession of all the facts about his father's dissolute character but nevertheless refuses to blame him, thereby implicitly rejecting the premise of Ibsen's play that makes the disease a metaphor for more abstract inherited evil: "Don't think it matters a damn who we come from or who did what to us and when and where. We are each responsible for what we are. No one else" (43). This moral argument is, however, complicated by the presence of an ulterior motive.

When Oliver feels his end approaching, he uses his argument about individual moral responsibility to impose on his mother the burden that he had earlier hoped Regina might take upon herself.

OLIVER: I didn't know my father. What are you talking about? Some kind of mystical connection? Come off it, Mother.

MRS AYLWARD: It must mean something.

OLIVER: Means bugger-all. Unless people are actually present, it means nothing. We are what we are. Regina was right. The only feelings that matter are the ones that are earned the hard way...

MRS AYLWARD: Don't you love me, Oliver? ...

OLIVER: Anyway, these are just words. It's action that proves things. You've got to prove your feelings over and over again. No matter what the cost.

MRS AYLWARD: Oh, I will prove myself, Oliver.

OLIVER: Got to be able to accept everything -

MRS AYLWARD: Oh, I do accept. I do, Oliver ... 
Different from Oswald's exhortation to his mother at this point in Ibsen's play, that she must be "patient" and "cheerful" (192), the verbal contract of having to accept "everything" in Kilroy's version obliges Mrs Aylward to prove her love for her son, on his terms, when the time comes to carry out Oliver's final wish. Where Oswald's mother says it was she "who gave [him] life", to which he replies that she can therefore "[t]ake it back" (196), Oliver's mother says, "I loved giving you life -", to which he counters, "Then love me by helping me die!" (62).

To the Catholic Church, euthanasia is murder and suicide is a sin; as far as Kilroy is concerned, however, "stereotypical morality is totally inadequate to account for human behaviour". Morality, he argues, is personal: it "is a process of constant vigilance, and of constant discovery" (Brennan and Dubost 127). When it becomes "systematized" or "ideological", as in organized religion, "then in fact, it ceases to be of all that much use in life... Morality is something that one discovers" (Brennan and Dubost 132). What Mrs Aylward finally discovers is a morally complex dilemma. Even if she can put aside the teachings of the Church, Oliver's rhetorical strategy - coercing her to do his bidding by appealing to her loving maternal instinct - puts her in an invidious position since it reiterates the gendered pattern she had earlier diagnosed, and condemned, in relation to her marriage. "Women are so easily tricked by appeals to their virtue", she had exclaimed then; "Make them feel good and they'll do anything ...". Regretting the hypocrisy of her own decision to conceal her marital unhappiness, she vowed, "Not any more, Oliver, I've learned my lesson" (Kilroy, Ghosts 56). In the face of her son's final appeal to her "love", then, she asks herself, while holding his bottle of suicide pills: "Oh, God, what am I going to do?" (63). Her dilemma puts into an ironic light the words with which she had earlier berated Fr Manning: that helping people, "doing good", sometimes causes great suffering, and that we can only "grope towards our morality every hour of every day of our lives" (15). When the sun rises at the conclusion of Kilroy's Ghosts, as it does in Ibsen's original, it therefore throws light not only on Oliver's rapidly deteriorating mental and physical condition, but also on his mother's discovery that moral questions can only be resolved through great personal struggle, and that, if she does decide to "love" her son by helping him die, that deed will be morally compromising in more ways than one, and the suffering as a consequence of "doing good" will be her own.

\section{Conclusion}

In a letter to Kilroy dated 8 November 1988, when Kilroy was still working on the play, Ryan expressed the reservation that the work in progress was "too much Ibsen, in his time, and not enough Tom, in our time". Kilroy himself, interviewed shortly after the opening of Ghosts in 1989, stated that, whereas his version of The Seagull stays comparatively close to Chekhov's original voice, his re-working of Ibsen's drama does more "violent action" to the original (O’Byrne 14). That action, however, is perhaps not "violent" enough. When Jenny Topper turned down the play for London's Hampstead Theatre in 1990, it was on the grounds that, from her "urban perspective", its outdated Ibsenite class structure and the melodrama were "at odds with the modern and all too realistic dilemma of AIDS". In her review of the play's 2002 revival, Emer O'Kelly argued that, given the transformation of Pastor Manders, a Protestant clergyman, into Fr Manning, a celibate Catholic priest, the adaptation's retention of the close relationship between the latter and Mrs Aylward was "infelicitous" (78). Kilroy himself, too, has suggested that in his version of Ghosts, "the transference into a Catholic culture" of Ibsen's material is "awkward" ("Playwrights" 189). Yet it could be argued that, in light of the play's thematic concern with moral hypocrisy, especially in relation to women, the lingering attraction between Mrs Aylward and Fr Manning should, in fact, have been played up. In 
1992, the Irish media reported that almost two decades earlier, Eamonn Casey, the popular Bishop of Galway, had embarked on a six-month love affair with Annie Murphy, an IrishAmerican who had sought his advice following a recent divorce. After she became pregnant and gave birth to a son (in a home for unwed mothers), Casey tried to make her give up the baby, which he called a "mistake". "He made it clear that through the adoption of this child, I would be cleansed", Murphy later recalled; "It was as if I was Mary Magdalene" (Hays). The expressions of outrage and condemnation sparked by the disclosure of the affair were aimed predominantly at Murphy, who found herself at the receiving end of a great deal of animosity from Catholic Ireland as well as Irish America. Had Kilroy chosen the provocative route of introducing a more overtly sexual frisson between Mrs Aylward, the unhappily married woman, and Fr Manning, the priest she consulted for comfort, his Irish version of Ghosts would have contained yet another predictive element, in addition to its anticipation of revelations about clerical abuse, the legalization of divorce, and the introduction of same-sex marriage. Whether the inclusion in his play of such a scandalous scenario would have led to public expressions of hostility like the ones that greeted the publication of Ibsen's Ghosts in 1881 must, of course, remain an open question.

\section{Works Cited}

"AIDS: The Facts". Irish Examiner. 15 May 1987. 3.

Battersby, Eileen. "Kilroy Is Here". The Irish Times. 2 October 1997. 13.

Brennan, Paul and Thierry Dubost. "An Interview with Thomas Kilroy, 2001". The Plays of Thomas Kilroy: A Critical Study, by Thierry Dubost. Jefferson and London: McFarland \& Company, 2007. 125-36.

Constitution of Ireland - Bunreacht na hÉireann. 18 September 2017. https://www.taoiseach.gov.ie/DOT/eng/Historical_Information/The_Constitution/Cons titution_of_Ireland_-_Bunreacht_na_h\%C3\%89ireann.html.

Constitution Review Group. "The Family": Constitution Review Group Report, 1995. 296$315 . \quad 18 \quad$ September 2017. https://web.archive.org/web/20110721123125/http://www.constitution.ie/reports/crg.p df

"Energetic Elsom”. The Irish Times. 14 October 1989. 25.

Fitz-Simon, Christopher. Comments on the script of "Ghosts" for Thomas Kilroy. N.d. 1988. NUIG, P103/165(9).

Hays, Constance L. "Mother of Bishop's Son Tells of Irish Love Affair". The New York Times. 9 May 1992. 22 July 2017. http://www.nytimes.com/1992/05/09/world/motherof-bishop-s-son-tells-of-irish-love-affair.html.

Ibsen, Henrik. From Ibsen's Workshop: Notes, Scenarios, and Drafts of the Modern Plays. Introduction by William Archer. New York: Charles Scribner's Sons, 1917.

- Ghosts. Ghosts and Three Other Plays by Henrik Ibsen. Trans. Michael Meyer. Garden City: Anchor Books, 1966. 125-97.

“Irish Bishops Urge 'No' Vote”. The Southern Star. 24 May 1986. 15.

Kilroy, Thomas. Letter to Phyllis Ryan. 25 February 1988. NUIG, P103/165(5).

- Programme Note. Ghosts: A New Version of Ibsen's Classic by Thomas Kilroy, directed by Michael Scott. Dublin Theatre Festival. 5 October 1989. NUIG, $\mathrm{P} 103 / 165(49)$.

. The Secret Fall of Constance Wilde. Oldcastle: Gallery Press, 1997.

Ghosts: After Ibsen. Oldcastle: Gallery Press, 2002. 
. Henry: After Henry IV. Pirandellos: Two Plays. Oldcastle: Gallery Press, 2007. 81134.

"Adaptation: A Privileged Conversation with a Dead Author". The Irish Times. 13 February 2010. 47.

Meyer, Michael. "Introduction". Ghosts and Three Other Plays by Henrik Ibsen. Trans.

Michael Meyer. Garden City: Anchor Books, 1966. 105-23.

Nowlan, David. "'Ghosts' at the Peacock”. The Irish Times. 6 October 1989. 12.

O'Brien, Cormac. "HIV and AIDS in Irish Theatre: Queer Masculinities, Punishment, and 'Post-AIDS' Culture'. Journal of Medical Humanities, 2017: 1-14. Advance online publication. https://doi.org/10.1007/s10912-017-9439-3.

O’Byrne, Robert. "Coming to Terms with Translating”. The Irish Times. 21 December 1989. 14.

O’Donnell, Mary. “Ibsen's Elegance and Doom”. Sunday Tribune. 8 October 1989. B3.

O'Kelly, Emer. "Ghost of Ibsen Haunts the Land". Sunday Independent. 20 April 2002. 78.

O'Toole, Fintan. "Murphy in the Underworld". The Irish Times. 7 October 1989. 25.

"Panel Discussion 1: Reading Kilroy". Across the Boundaries: Talking about Thomas Kilroy. Ed. Guy Woodward. Dublin: Carysfort Press, 2014. 59-74.

"Panel Discussion 2: Directing Kilroy". Across the Boundaries: Talking about Thomas Kilroy. Ed. Guy Woodward. Dublin: Carysfort Press, 2014. 75-87.

"Playwrights Speak Out - Roundtable Discussion on Translation and Adaptation with Thomas Kilroy and Michael West”. Ibsen and Chekhov on the Irish Stage. Eds. Ros Dixon and Irina Ruppo Malone. Dublin: Carysfort Press, 2010. 175-91.

Roche, Anthony. "An Interview with Thomas Kilroy". Irish University Review 32.1 (2002): 150-58.

Ryan, Phillis. Letter to Thomas Kilroy. 30 December 1987. NUIG, P103/165(2). - Letter to Thomas Kilroy. 8 November 1988. NUIG, P103/165(17).

- Programme Note. Ghosts: A New Version of Ibsen's Classic by Thomas Kilroy, directed by Michael Scott. Dublin Theatre Festival. 5 October 1989. NUIG, P103/165(49).

"Statement on AIDS Rapped". Irish Examiner. 19 January 1987. 6.

Topper, Jenny. Letter to Thomas Kilroy. 21 August 1990. NUIG, P103/164(2).

Wallace, Arminta. "Why 'Ghosts' Will Walk the Peacock Stage this Week". The Irish Times. 3 October 1989. 14.

Williams-Rude, Beatrice. "Ghosts after Ibsen - Haunted by Secrets and Lies". Theater Pizzazz. 6 March 2015. 7 March 2015. http://theaterpizzazz.com/ghosts-after-ibsenhaunted-by-secrets-and-lies/.

Received: 2 October $2017 \quad$ Revised version accepted: 5 January 2018

José Lanters is Professor of English at the University of Wisconsin-Milwaukee, where she also co-directs the Center for Celtic Studies. Her recent major publications include The "Tinkers" in Irish Literature (Irish Academic Press, 2008), and Beyond Realism: Experimental and Unconventional Irish Drama since the Revival, co-edited with Joan FitzPatrick Dean (Rodopi, 2015). Her new book, The Theatre of Thomas Kilroy: No Absolutes, is published by Cork University Press (2018). She is a former president of the American Conference for Irish Studies (ACIS) and currently serves as the vice chair for North America on the executive committee of the International Association for the Study of Irish Literatures (IASIL).

lanters@uwm.edu 